\title{
Patau Syndrome with Genotype 47,XY, + 13,t(13:18)
}

\author{
Vanda Elfira, ${ }^{1,2}$ Fiva Aprilia Kadi, ${ }^{2}$ Bremmy Laksono, ${ }^{3}$ Sjarif Hidajat Effendi ${ }^{2}$ \\ ${ }^{1}$ Kebayoran Lama General Hospital South Jakarta, Indonesia, ${ }^{2}$ Department of Child Health Faculty of Medicine \\ Universitas Padjadjaran/Dr. Hasan Sadikin General Hospital Bandung, Indonesia, ${ }^{3}$ Department of \\ Biochemistry and Molecular Biology, Faculty of Medicine Universitas Padjadjaran, Bandung, Indonesia
}

\begin{abstract}
Trisomy 13 (Patau syndrome) is cytogenetically classified as a 47,XY,+13 or 47,XX,+13, due to nondisjunction at meiosis I or II, or at mitosis (mosaicism), and partial trisomy due to translocation. Patau syndrome is one of the most common chromosomal anomalies with an estimated incidence of about 1/10,000 births characterized by the presence of cleft lip and/or palate, post axial polydactyly, low set ears, rocker-bottom feet, cryptorchidism, and congenital heart disease. This was a case report of a newborn baby in Dr. Hasan Sadikin General Hospital Bandung in January 2016 with translocation of chromosome 13 segment to chromosome 18 or 47,XY,+13,t(13:18).
\end{abstract}

Key words: Patau syndrome, Trisomy 13, translocation

\section{Sindrom Patau dengan Genotype 47,XY,+13,t(13:18)}

\begin{abstract}
Abstrak
Trisomi 13 (sindrom Patau) secara sitogenetik diklasifikasikan 47,XY,+13 atau 47,XX,+13, disebabkan oleh kegagalan pemisahan pada meiosis I atau II, atau pada mitosis (mosaicism) dan trisomi parsial yang disebabkan oleh translokasi. Sindrom Patau merupakan salah satu anomali kromosom yang paling sering dengan insidensi sekitar 1/10.000 kelahiran, dengan karakteristik fenotipe seperti celah bibir dan atau celah langit-langit, postaxial polydactyly, low set ears, rocker bottom feet, kriptokismus, serta kelainan jantung kongenital. Dilaporkan kasus sindrom Patau pada bayi baru lahir di Rumah Sakit Dr. Hasan Sadikin Bandung pada Januari 2016 yang menunjukkan segmen dari kromosom 13 translokasi ke kromosom 18 atau 47,XY,+13,t(13:18).
\end{abstract}

Kata kunci: Sindrom patau, Trisomi 13, translokasi

Corresponding Author: Vanda Elfira, Kebayoran Lama General Hospital South Jakarta, Jalan Jatayu, Kebayoran Lama Selatan, South Jakarta, Indonesia, Email: vanda.elfira@yahoo.co.id 


\section{Introduction}

Trisomy 13 or Patau syndrome is a multiple congenital anomalies syndrome characterized by three cardinal signs: lip or cleft palate, microphtalmia, and postaxial polydactyly on extremities. The global prevalence of this disease is around $1 / 10,000$ births and its frequency increases to 100 times in spontaneous abortion. ${ }^{1,2}$ This syndrome is often considered as a "lethal disorder" because of its poor outcome. Fetus with Patau syndrome has a worse prognosis.,4 About $67 \%$ of fetus diagnosed with Patau syndrome experience spontaneous abortion or intrauterine fetal death while the other $50 \%$ died during the first week and only about $9 \%$ babies survive their first year. ${ }^{3}$ After the prenatal diagnosis, a lot of women choose to terminate their pregnancy while some choose to continue. ${ }^{4}$ This is a case report reporting a case of Trisomy 13 with translocation to chromosome 18 or $47, \mathrm{XY},+13, \mathrm{t}(13: 18)$.

\section{Case}

A 30-years-old G2P1A0 woman in 39 weeks of gestation gave birth to a son by caesarian section. The new born infant weighed 2,550 gr with APGAR scores of 8 and 9 during the first and fifth minutes of life. The newborn was observed to have distinctive clinical features that include dismorphic face, hipertelorism, low set ears, flat nose, short and wide neck, postaxial polydactyly, rocker bottom feet, cryptochidism, hypospadia penile type, and a small patent ductus arteriosus. The result of the post-natal ultrasonography presented that the baby also had atrial septal defects but no lip or cleft palate was seens. No history of congenital abnormalities was identified from either side of parents' family. After the peripheral blood examination was performed using the conventional chromosome analysis and Fluorescence in situ hybridization (FISH) method, it trisomy 13 with translocation in chromosome 18 was discovered. The genotype pattern of the chromosome was translocation, showing that this was a hereditary condition. Recurrency might happen in the future.

\section{Discussion}

Trisomy 13, also known as Patau syndrome, is a abnormal chromosome condition which is linked with severe intelectual disability and physical abnormality in many parts of the body. ${ }^{5}$ This syndrome is also the third most common autosomal trisomies after trisomy 21 (Down syndrome) and trisomy 18 (Edward syndrome). ${ }^{2,6,7}$ This syndrome has been found since more than 40 years ago. Until now, the survival rate of baby with Patau syndrome has not changed much, which is about $30-60 \%$ in the first week, $20-40 \%$ in the first month, and $3-10 \%$ in the first year of life. Survival rate after 1 year is not common. ${ }^{6}$ This syndrome is seen in 1 out of 10,000-20,000 births. ${ }^{5,8,9}$ Older age has been associated with the risk of giving birth baby with Patau syndrome. ${ }^{5}$ This condition is quite life threatening, thus it correlates with the high rate of spontaneous abortion, intrauterin fetal death, and short life expectancy., ${ }^{9,10}$ Hence, early detection of chromosome abnormalities is very important to diagnose this trisomy during the prenatal period..$^{10}$

The majority of Trisomy 13 case is not hereditary. On the contrary, it occurs due to random events during the formation of ovum and sperm in healthy parents. The nondisjunction causes those cells to have abnormal number of chromosome, such as the presence of extra 13 chromosomes in the egg/sperm. The atypical reproductive cells will lead to three copies of chromosome 13 in every cell of the fetus (while normally only two copies are present). This genetic material might disturb the normal development and produces the clinical features of Trisomy $13 .{ }^{5}$ The parents of Patau syndrome patient also need to be checked for chromosomal aberration, because they might be a carrier of Robertsonian translocation which can cause chromosomal deletion or addition and result in syndrome of multiple malformations, including trisomy 13 (Patau syndrome). An unaffected person with a balanced translocation involving chromosome 13 (Robertsonian or other) has an increased chance to pass extra material from chromosome 13 to offsprings with each pregnancy. However, the exact recurrence risk may depend on which parent is a carrier, the type of translocation present, and the specific chromosome(s) involved. Recurrence is more common when the translocation carrier is the mother.

Trisomy 13 can also happen when the a part of chromosome 13 translocates to other chromosome during the formation of reproductive cells (ovum and sperm) or during the early development of fetus. The fetus will have two copies of normal chromosome 13 and one extra copy of chromosome 13 which will 
bind with other chromosomes. ${ }^{5}$

A fraction of patients with trisomy 13 will have extra copy of chromosome 13 in some parts of the body cells. This condition is known as Mosaic Trisomy 13. The severity of the condition depends on the type and number of cells which has the extra chromosome. The clinical manifestation of mosaic trisomy 13 is often lighter. ${ }^{5}$

Patau syndrome is characterized with three cardinal signs: lip or cleft palate, microphtalmia, and postaxial polydactyly. ${ }^{1,2,11}$ Other than that, other signs that can be found is scalp defect, holoprocenphaly, congenital heart disease, ear disorder, nose disorder, and severe intelectual development deficiency. ${ }^{12}$ Commonly, the most severe manifestation of Patau syndrome is holoprocencephaly which can affect the brain (one cerebri hemisphere, cerebri ventricle, corpus calosum agenesis), ocular structure (microphtalmia.anopthalmia or cyclopia) and frontal bud (proboscis, hipertelorism, velopalatine median cleft). ${ }^{11}$

Several congenital heart diseases which is often seen in these trisomy are ventricular septal defect, patent ductus arteriosus, and atrial septal defect. The abnormalities of the eye include micropthalmia, coloboma iris, retina dysplasia, and helics auricle abnormality. Some skin disorders might also occur, including capillary hemangioma on the forehead; axial triadii on the distal palmar; simian crease; hipoconvex and narrow nails' fingers flexion with or without overlapping and camtodactyly; and hands polydactyly. Some bone abnormalities such as thin posterior ribs and pelvic hipoplasia could also happen. In males, cryptocydism/abnormal scrotum could be observed while bicornuat uterus is seen in females. Other malformations could happen and are followed by severe psychomotoric disorder. ${ }^{7}$

This patient only shows one cardinal sign, which is postaxial polydactyly, while the other two signs are not found. The ocular abnormality experienced by the patient is hipertelorism; heart disorders including patent ductus arteriosus and atrial septal defect; ear disorder in the form of low set ears; nose disorder in the form of flat nose; bone disorder including rocker bottom feet and cryptocysmus; genital abnormality in the form of hipospadia penile type; and other disorders including dismorphic face with short and wide neck.

The diagnosis of Patau syndrome was made based on clinical manifestations observations as well as citogenic and molecular genetic tests. The citogenic test was performed using fluoresncence in situ hybridizaion (FISH) and chromosome analysis while the genetic molecular test was done through the detection of homozigosity and sequence analysis of the whole coding region and deletion/duplication analysis. ${ }^{13}$ In this patient, FISH test and conventional chromosome analysis was performed using peripheral blood sample to detect any translocation. ${ }^{14}$ The test result presented a translocation of chromosome 13 to chromosome 18 or $47, \mathrm{XY},+13, \mathrm{t}(13: 18)$.

Patau syndrome can be diagnosed during prenatal period using various methods including using fetal genetic material with amniocentesis or chorionic villus sampling which are considered invasive. ${ }^{6}$ Other non-invasive methods include ultrasonography and maternal serum marker examination, although its sensivity and specivity are limited. Various alternative methods are developed for early detection, including, among others, by using maternal plasma DNA sequencing. ${ }^{15}$ During the last 30 years, early detection of Patau syndrome is performed by amniocentesis and ultrasonography examination in the second and third trimesters of pregnancy. After prenatal diagnosis, parents are given the freedom to choose pregnancy termination through induced abortion or to continue the pregnancy eventhough the fetus has been diagnosed with severe fetal abnormalities. ${ }^{10}$

During the process of decision making by the parents, it is very important to do counseling about the prognosis and the risk of intrauterin fetal death, death of the newborn/infant, or the longterm survival rate. ${ }^{6,10}$ The management for fetus in the third trimester, if the mother decided to continue her pregnancy, is quite complicated which is due to the high risk for death in newborn or infant with Patau syndrome. ${ }^{7}$

Other than that, the most important issue regarding the management and counseling of baby with Patau syndrome is the poor prognosis. The patient will most likely experience severe mental retardation, frequent seizures, and failure to thrive. Because of that, operative and orthopedic corrective procedure should be done as early as possible to see the outcome in the first few months. A study in Japan showed that babies born with Patau syndrome who receive active intensive care in NICU and able to survive until 60 days old have a good chance to have a long-term life. ${ }^{7}$ Another study in Austria showed that the mean survival time for babies with Trisomy 13 is between 6 hour to a maximum of 87 hours. ${ }^{10}$

Prenatal screening for fetal chromosome 
abnormality in the second trimester of pregnancyis very important, especially for Trisomy 13. This will motivates the parents to be involved in active counseling after prenatal diagnosis. It is very important for parents of fetus with chromosome abnormality to have a good understanding about the prognosis of pregnancy's outcome and the baby, which will be very much determined by the postpartum management. The reasons why parents decide to continue their pregnancy despite the chromosome abnormality being very lethal for the fetus varies; hence, continung the pregnancy can be interpreted as an effort to extend the time spent between mother and fetus and parents should also be prepared to part with the fetus. Other than that, parents also need to be given some updated accurate informations so that they can prepare themselve from various events which are parts of the "natural outcome" of this unpredictable abnormality including intauterine fetal death, stillborn, and low fetal survival rate, as well as various maternal risks. ${ }^{10}$

This case provides an insight of the importance of considering prenatal testing in all pregnancies when one of the parents is a balanced carrier of a Robertsonian translocation due to the risk of aneuploidy. Genetic counseling and genetic testing should be offered to families with possible carriers of chromosomal translocations.

\section{References}

1. Feben C, Kromberg J, Krause A. An unusual case of trisomy 13. SAJCH. 2015;9(2):61-2.

2. Mbuyi MS, Lumaka A, Yogolelo AB, Lubala KT, Lukusa TP, Kalenga MP, et al. Preaxial polydactyly of the foot: variable expression of trisomy 13 in a case from central Africa. Hindawi. 2014;2014:1-5.

3. Rosa RFM, Sarmento MV, Polli JB, Groff DDP, PetryP, Mattos VFD, et al. Gestational, perinatal and family findings of patients with Patau syndrome. Rev Paul Pediatr. 2014;31(4):459-65.

4. Janvier A, Farlow B, Wilfond BS. The experience of families with children with trisomy 13 and 18 in social networks. Pediatrics. 2012;130(2):293-8.

5. NIH. Genetic home reference. trisomy 13. Bethesda: National Library of Medicine; 2018 [cited 2018 June 27]. Available from: https://ghr.nlm.nih.gov/condition/ trisomy-13

6. Barry SC, Walsh CA, Burke AL, McParland P, McAuliffe FM, Morrison JJ. Natural history of fetal trisomy 13 after prenatal diagnosis. Am J Med Genet A. 2015;167(1):147-50.

7. Tsukada K, Imataka G, Suzumura H, Arisaka 0 . Better prognosis in newborns with trisomy 13 who received intensive treatments: a retrospective study of 16 patients. Cell biochembiophys. 2012;63(3):191-8.

8. Aypar E, Yildirim MS, Sert A, Ciftci I, Odabas D. A girl with metopic synostosis and trisomy 13 mosaicism: case report and review of the literature. Am J Med Genet A. 2011;155(3):638-41.

9. Bruns D. Birth history, physical characteristics, and medical conditions in long-term survivors with full trisomy 13 . Am J Med Genet A. 2011;155(11):2634-40.

10. Lakovschek IC, Streubel B, Ulm B. Natural outcome of trisomy 13, trisomy 18, and triploidy after prenatal diagnosis. Am J Med Genet A. 2011;155(11):2626-33.

11. Caba L, Rusu C, Butnariu L, Panzaru M, Braha $\mathrm{E}$, Volosciuc M, et al. Phenotypic variability in Patau syndrome.Rev Med ChirSoc Med Nat Iasi. 2013;117(2):321-7.

12. Nelson KE, Rosella LC, Mahant $S$, Guttmann A. Survival and surgical interventions for children with trisomy 13 and 18. JAMA. 2016;316(4):420-8.

13. NCBI. Complete trisomy 13 syndrome. 2018. Bethesda: National Center for Biotechnology Information; 2018 [cited 2018 June 27]. Available from: https://www.ncbi.nlm.nih. gov/gtr/conditions/C0152095/

14. O'Connor C. Fluorescence in situ hybridization (FISH). Nature Education. 2008;1(1):171

15. Chen EZ, Chiu RW, Sun H, Akolekar R, Chan KA, Leung TY, et al. Noninvasive prenatal diagnosis of fetal trisomy 18 and trisomy 13 by maternal plasma DNA sequencing. PloS one. 2011;6(7):e21791. 